\title{
Pengaruh Penerapan Metode Pembelajaran Aktif Modeling The Way terhadap Kemampuan Komunikasi Matematis Ditinjau dari Kemampuan Awal Siswa SMK Taruna Pekanbaru
}

\author{
Kiky Rizki Rahmayanti, Hasanuddin, Zulkifli Nelson \\ Mathematics Education Department, Universitas Islam Negeri Sultan Syarif Kasim Riau \\ rkikyrizki@yahoo.com,hasanuddin@uin-suska.ac.id, zulkifli.nelson@uin-suska.ac.id
}

\begin{abstract}
ABSTRAK. Penelitian ini bertujuan untuk mengetahui pengaruh penerapan pembelajaran aktif Modeling The Wayterhadap kemampuan komunikasi matematis ditinjau dari kemampuan awal siswa SMK Taruna Pekanbaru. Populasi dalam penelitian ini adalah seluruh siswa kelas XISMK Taruna Pekanbaru tahun ajaran 2016/2017. Sampel penelitian ini dipilih dengan menggunakan teknik simple random sampling, terpilih kelas X TAV sebagai kelas eksperimen kelas X TKR2 sebagai kelas kontrol yang berjumlah 29 dan 30 siswa setiap masing-masing kelas. Teknik analisis data menggunakan uji-t dan anova dua arah (two factorial design). Instrumen yang digunakan adalah tes uraian untuk mengukur kemampuan awal dan kemampuan komunikasi matematis siswa. Hasil penelitian menunujukkan bahwa terdapat pengaruh pembelajaran aktif Modeling The Wayterhadap kemampuan komunikasi matematis siswa. Pengujian hipotesis menunjukkan bahwa terdapat perbedaan antara kelas kontrol dan eksperimen. Hasil nya di peroleh bahwa $t_{\text {hitung }} \geq t_{\text {tabel }}$ pada taraf signifikan $5 \%$ diperoleh $2,06 \geq 2,042$. Tidak terdapat perbedaan kemampuan awal siswa kelas eksperimen dan kelas kontrol yang hasil nya di peroleh $t_{\text {hitung }} \leq t_{\text {tabel }}$ pada taraf signifikan $5 \%$ yakni $0,5 \leq 2,042$. Adapun besar kontribusi kemampuan awal terhadap kemampuan komunikasi adalah $23,1 \%$ dan sisanya di tentukan oleh faktor lain. Tidak terdapat interaksi antara metode pembelajaran dan kemampuan awal siswa terhadap kemampuan komunikasi matematis siswa.Dengan demikian secara umum pembelajaran aktifModeling The Wayberpengaruh terhadap kemampuan komunikasi matematis ditinjau dari kemampuan awal siswa SMK Taruna Pekanbaru.
\end{abstract}

Kata kunci: Modeling The Way, Kemampuan Komunikasi Matematis, Kemampuan Awal Matematis.

\section{PENDAHULUAN}

Kemampuan komunikasi dalam pembelajaran matematika merupakan suatu hal yang penting mengingat matematika sarat dengan istilah dan simbol. Bagi siswa, melakukan komunikasi matematis bukan hal yang mudah. Hamzah B. Uno mengemukakan matematika merupakan alat berpikir, berkomunikasi dan memecahkan berbagai persoalan (Uno, 2009, p.109). Proses berpikir siswa tidak dapat secara langsung tertangkap panca indera, agar dapat diamati siswa perlu mengkomunikasikannya secara lisan atau tertulis.

Adapun tujuan pembelajaran matematika di jenjang pendidikan dasar dan menengah adalah sebagai berikut, dijelaskan agar siswa memiliki kemampuan salah satunya yaitu Mengkomunikasikan gagasan dengan simbol, tabel, diagram atau media lain untuk memperjelas masalah (Depdiknsa, 2006). Berdasarkan tujuan pembelajaran matematika di sekolah, kemampuan komunikasi matematis merupakan salah satu kemampuan yang penting diajarkan dalam pembelajaran matematika. Berbekal kemampuan intelektual yang memadai siswa-siswa mampu mengkomunikasikan dan membuat hubungan antara satu gagasan dengan gagasan yang lain dalam memecahkan masalah. 
Beberapa riset tentang kemampuan komunikasi telah dilakukan oleh beberapa peneliti. Kemampuan komunikasi dapat ditingkatkan melalui Contextual Teaching Learning (Febrinal, 2016). Kemampuan komunikasi dapat ditingkatkan melalui Pendekatan SAVI (Somatis, Auditori, Visual, Intelektual) (Zainuddin, et.al., 2017). Kemampuan komunikasi dapat ditingkatkan melalui pembelajaran kooperatif tipe teams-games-tournaments (Asnawati, 2016).

Berdasarkan uraian diatas terlihat bahwa penelitian yang dilakukan oleh peneliti tentang pengaruh penerapan metode pembelajaran aktif modeling the way terhadap kemampuan komunikasi matematis ditinjau dari kemampuan awal siswa SMK Taruna Pekanbaru dapat berpengaruh dan dapat menjadi pembaharuan metode pembelajaran bagi guru mata pelajaran, karena metode pembelajaran aktif modeling the way dapat meningkatkan kemampuan komunikasi matematis siswa yang ditinjau dari kemampuan awal siswa dengan baik dibandingkan siswa yang diajar dengan pembelajaran konvensional.

Rendahnya kemampuan komunikasi siswa tidaklah semata-mata kekurangan siswa. Akan tetapi, bisa juga disebabkan kekurangan guru dalam proses pembelajaran. Berdasarkan hasil observasi dan wawancara yang dilakukan peneliti pada saat melaksanakan program pengalaman lapangan (PPL) tanggal 29 September 2016 di SMK Taruna Pekanbaru kenyataannya terdapat masalah dalam pembelajaran matematika. Salah satu permasalahan yang dialami oleh siswa tersebut adalah rendahnya kemampuan siswa dalam komunikasi matematis.

Guru telah melakukan usaha untuk mengatasi permasalahan rendahnya komunikasi matematis siswa. Usaha yang telah dilakukan guru yaitu guru telah mengadakan tanya jawab dengan siswa, mengajak siswa untuk berdiskusi. Namun usaha guru tersebut belum menunjukkan hasil yang memuaskan. Hal ini disebabkan, pada saat proses pembelajaran berlangsung kegiatan proses belajar mengajarnya masih didominasi oleh guru sehingga banyak siswa yang diam dan hanya sebagian kecil siswa yang aktif mengikuti proses pembelajaran.

Komunikasi matematis siswa yang rendah merupakan hal yang harus di tindak lanjuti. Karena dalam proses pembelajaran matematika, komunikasi matematis merupakan hal yang sangat penting dan diperlukan oleh siswa, mengingat bahwa kemampuan komunikasi matematis tersebut akan sangat membantu siswa untuk mengembangkan kemampuan bahasa dan keterampilan sosial mereka. Berdasarkan dari permasalahan tersebut, perlu usaha untuk meningkatkan komunikasi matematis siswa dengan menggunakan metode pembelajaran yang tepat. Oleh karena itu, dikembangkan metode pembelajaran yang dapat meningkatkan komunikasi matematis dan melibatkan siswa untuk mandiri, kreatif dan aktif. Salah satu cara belajar yang baik dan dapat meningkatkan komunikasi matematis dan melibatkan siswa untuk mandiri, kreatif dan aktif adalah menerapkan pembelajaran menggunakan metode pembelajaran aktif modeling the way (Ratnadewi, et.al., 2016).

Metode pembelajaran aktif modeling the way sebagai salah satu metode dalam pembelajaran matematika yang memungkinkan siswa untuk mengembangkan pola pikirnya sesuai dengan minat dan kemampuan masing- masing. Hal ini disebabkan karena pada metode pembelajaran aktif modeling the way adalah metode yang memberi kesempatan kepada siswa untuk mempraktekkan spesifik yang di pelajari di kelas melalui demonstrasi. Melalui metode pembelajaran aktif modeling the way siswa dapat menemukan sesuatu yang baru dalam penyelesaian suatu masalah, khususnya masalah yang berkaitan dengan matematika (Zaini, et.al., 2008). Metode pembelajaran aktif modeling the way ini siswa dapat mengemukakan pemikirannya, saling bertukar pendapat, saling bekerja sama dengan teman dalam kelompoknya untuk membuat suatu skenario kerja. Hal ini, memungkinkan dapat meningkatkan motivasi siswa untuk mengkaji dan menguasai materi pelajaran matematika sehingga nantinya akan meningkatkan komunikasi matematika siswa tersebut (Ratnadewi, et.al., 2016). Pada pembelajaran yang telah diperbaharui, siswa tidak dipandang lagi sebagai objek atau sasaran belajar. Siswa memiliki peluang aktivitas yang cukup untuk mengkomunikasikan matematika. 
Faktor lain yang juga menentukan keberhasilan siswa dalam menerima pelajaran adalah kemampuan awal. Dengan melihat kemampuan awal siswa, dapat diketahui sejauh mana siswa telah mengetahui materi yang telah disajikan. Kemampuan awal siswa penting untuk diketahui guru sebelum ia mulai dengan pembelajarannya, karena dengan demikian dapat diketahui: a) apakah siswa telah mempunyai pengetahuan yang merupakan prasyarat untuk mengikuti pembelajaran; b) sejauh mana siswa telah mengetahui materi apa yang akan disajikan.

Kemampuan awal diperlukan pada metode pembelajaran aktif modeling the way karena pada saat pembagian kelompok berdasarkan kemampuan awal sehingga setiap kelompok memiliki anggota yang heterogen. Hal ini bertujuan agar dalam proses pembelajaran metode pembelajaran aktif modeling the way terdapat saling ketergantungan baik itu kemampuan awal tinggi, sedang, maupun rendah sehingga proses penyelidikan suatu masalah yang ada dalam bahan ajar yang berupa Lembar Kegiatan Siswa (LKS) bisa terselesaikan dengan baik sesuai yang diharapkan guru.

Berdasarkan latar belakang yang telah dikemukakan diatas, peneliti berkeinginan untuk melakukan penelitian dengan judul "Pengaruh Penerapan Metode Pembelajaran Aktif Modeling The Way terhadap Kemampuan Komunikasi Matematis Ditinjau dari Kemampuan Awal Siswa SMK Taruna Pekanbaru".

Berdasarkan latar belakang yang telah dikemukakan sebelumnya, maka tujuan yang ingin dicapai dalam penelitian ini ialah. Pertama, untuk menyelidiki pengaruh perbedaan kemampuan komunikasi matematika siswa yang belajar menggunakan pembelajaran aktif Modeling The Way dengan siswa yang belajar menggunakan pembelajaran konvensional. Kedua, untuk menyelidiki perbedaan kemampuan awal siswa kelas eksperimen dan kelas kontrol. Ketiga, untuk menyelidiki besarnya kontribusi kemampuan awal siswa terhadap kemampuan komunikasi. Keempat, untuk menyelidiki pengaruh interaksi antara metode pembelajaran dengan kemampuan awal terhadap kemampuan komunikasi matematis.

\section{TINJAUAN LITERATUR}

\section{Modeling The Way}

Metode Modeling The Way adalah suatu metode pembelajaran aktif yang memberi kesempatan kepada siswa untuk mempraktekkan keterampilan spesifik yang dipelajari di kelas melalui demonstrasi atau suatu metode pembelajaran aktif yang dilaksanakan dengan cara guru memberikan skenario suatu sub bahasan untuk didemonstrasikan siswa di depan kelas, sehingga menghasilkan ketangkasan dengan keterampilan atau skill dan profesionalisme (Zaini, et.al., 2008).

Selanjutnya, Zaini (2008) memaparkan angkah-langkah metode modeling the way adalah sebagai berikut: a) Setelah pembelajaran satu topik tertentu, carilah topik-topik yang menuntut siswa untuk mencoba atau mempraktekkan keterampilan yang baru diterangkan. b) Bagilah siswa ke dalam beberapa kelompok kecil sesuai dengan jumlah mereka. Kelompok-kelompok ini akan mendemonstrasikan suatu keterampilan tertentu sesuai dengan skenario yang di berikan (minimal 3 atau 4 orang). c) Beri siswa waktu 10-15 menit untuk menciptakan skenario kerja. d) Beri waktu 5-7 menit untuk berlatih., dan e) Kemudian salah satu kelompok di minta mendemonstrasikan kerja. Setelah demonstrasi selesai, beri kesempatan pada kelompok yang lain untuk memberikan masukan atas demonstrasi yang dilakukan.

\section{Kemampuan Komunikasi Matematika}

Kemampuan komunikasi matematika merupakan kemampuan dalam hal menjelaskan suatu algoritma dan cara unik untuk pemecahan masalah, kemampuan siswa mengkonstruksi dan 
menjelaskan sajian dunia nyata secara grafik, kata-kata/kalimat, persamaan, tabel dan sajian secara fisik atau kemampuan siswa memberikan dugaan tentang gambar geometri (Shadiq, 2009).

Indikator yang menunjukkan kemampuan komunikasi antara lain: a) Kemampuan menulis, yaitu berupa kemampuan memberikan penjelasan dan alasan secara matematika dengan bahasa yang benar dan mudah dipahami. b) Kemampuan menggambar, yaitu meliputi kemampuan siswa mengungkap ide-ide matematika dalam bentuk gambar, diagram atau grafik. c) Kemampuan ekspresi matematika, yaitu kemampuan membuat model matematika.

\section{Kemampuan Awal}

Kemampuan awal siswa adalah salah satu faktor dari aspek pribadi siswa yang juga merupakan hal penting dalam proses belajar mengajar. Kemampuan awal merupakan prasyarat yang diperlukan oleh siswa dalam mengikuti proses belajar mengajar (Bano, 2012).

\section{METODE}

Penelitian ini dilaksanakan di SMK Taruna Pekanbaru, pada semester genap tahun ajaran 2016/2017. Penelitian ini akan dilaksanakan selama \pm 1 bulan (April hingga Mei). Desain yang digunakan dalam penelitian ini adalah Posttest Only Control Design.Populasi dalam penelitian ini adalah semua siswa kelas X SMK Taruna Pekanbaru tahun ajaran 2016/2017. Cara pengambilan sampel dengan simple random sampling, dengan kelas XTAV sebagai kelas eksperimen dan X TKR 2 sebagai kelas kontrol.

Instrumen yang digunakan dalam penelitian berupa tes kemampuan awal dan tes kemampuan komunikasi matematis. Hasil tes inilah yang menjadi data utama analisis. Berdasarkan pengumpulan data yang dilakukan melalui tes tersebut, diperoleh jenis data kuantitatif. Data ini diperoleh melaui tes KAM dan tes kemampuan komunikasi matematis terhadap sampel penelitian (siswa keals X TAV dan X TKR2). Setelah data diperoleh, kemudian dianalisis tahap pertama: penguji persyaratan statistik yang diperlukan sebagai dasar dalam pengujian hipotesis, yaitu pengujian normalitas sebaran data subyek sampel dan uji homogenitas varians. Tahap kedua: menyelidiki pengaruh penerapan metode pembelajaran aktif Modeling The Way dan interaksi pembelajaran aktif Modeling The Way ditinjau dari kemampuan awal terhadap kemampuan komunikasi matematis siswa SMK Taruna Pekanbaru. Dengan menggunakan uji-t, korelasi pearson product moment dan two ways anova.

Teknik analisis data yang digunakan dalam penelitian ini adalah tes t, uji korelasi (Pearson Product Moment), dan anova dua arah (two factorial design). Sebelum melakukan hipotesis dengan anova dua jalur, ada tiga syarat yang harus dilakukan yaitu: a) Uji Normalitas, b) Uji Homogenitas Variansi, dan c) Uji Hipotesis. Sesuai dengan rumus masalah penelitian, maka teknik yang digunakan dalam menganalisis data untuk menguji hipotesis 1,2 menggunakan uji t jika datanya berdistribusi normal dan homogen, jika tidak homogen maka dengan uji t'.Hipotesis ke 3 menggunakan Uji Kolerasi (Pearson Product Moment).Kemudian untuk hipotesis ke 4 menggunakan anova 2 arah.

\section{HASIL}

Penelitian ini dilaksanakan di SMK Taruna Pekanbaru pada semester genap, dimana yang menjadi sampel penelitian adalah kelas X TAV sebagai kelas eksperimen sebanyak 29 orang siswa dan kelas X TKR2 sebagai kelas kontrol sebanyak 30 orang siswa. Dalam penelitian ini, peneliti menyusun instrumen penelitian dalam bentuk tes essay dengan jumlah soal sebanyak 10 butir soal. Tes yang diberikan kepada sampel penelitian telah diuji coba dan dihitung validitas serta 
reliabilitasnya terlebih dahulu. Pengujian tes ini diberikan kepada siswa kelas X(sepuluh) dan kelas $\mathrm{XI}$ (sebelas) di sekolah yang berbeda.

Sesuai dengan rumusan masalah penelitian, maka teknik yang digunakan dalam menganalisis data untuk menguji hipotesis 1, 2, menggunakan uji t. Tujuan dari uji ini adalah untuk mengetahui apakah komunikasi matematis siswa kelas eksperimen lebih baik dari rata-rata hasil komunikasi matematis kelas kontrol. Uji yang dilakukan dengan kriteria jika nilai signifikan yang diperoleh lebih kecil dari 0,05 maka $\mathrm{H}_{1}$ diterima, jika nilai signifikan yang diperoleh lebih besar dari 0,05 maka $\mathrm{H}_{0}$ diterima. Untuk hipotesis ke 3 menggunakan uji korelasi. Dan untuk menguji hipotesis 4 menggunakan anova dua arah.

a. Terdapat perbedaan kemampuan komunikasi matematis antara siswa yang mengikuti pembelajaran dengan metode Modeling The Way dengan siswa yang mengikuti pembelajaran langsung. Hal ini dapat dilihat dari nilai thitung 2,06 dan ttabel 2,042 pada taraf signifikan 5\%.

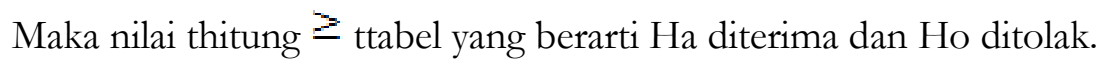

b. Tidak terdapat perbedaan kemampuan awal siswa kelas eksperimen dan kelas kontrol. Hal ini dapat dilihat dari nilai thitung 0,5 dan ttabel 2,042 pada taraf signifikan 5\%. Maka nilai thitung $\leq$ ttabel yang berarti Ha ditolak dan Ho diterima.

c. Adanya kontribusi yang cukup yang di berikan kam terhadap kemampuan komunikasi matematis siswa yakni $23,1 \%$ dan sisanya $76,9 \%$ di tentukan oleh variabel lain.

d. Tidak terdapat interaksi antara kemampuan awal siswa terhadap kemampuan komunikasi matematis. Hal ini dapat dilihat dari hasil perhitungannya yaitu nilai $\mathrm{Fh}$ yang diperoleh adalah 21,58 dengan Fk 317. Dengan kesimpulan nilai thitung $\leq$ ttabel yang berarti $\mathrm{Ha}$ ditolak dan Ho diterima.

\section{PEMBAHASAN}

Berdasarkan analisis data tentang kemampuan komunikasi matematis siswa pada pokok bahasan geometri dimensi tiga bahwa mean menunjukkan kemampuan komunikasi matematis yang menggunakan pembelajaran aktif Modeling The Way lebih tinggi dari mean siswa yang menggunakan model pembelajaran konvensional. Sebagaimana yang dikatakan Sugiyono bahwa jika kelompok treatment lebih baik daripada kelompok kontrol, maka perlakuan yang diberikan pada kelompok treatment berpengaruh positif (Sugiyono, 2013). Hasil analisis tersebut mendukung rumusan masalah yang pertama yaitu terdapat perbedaan kemampuan komunikasi matematis siswa yang belajar menggunakan pembelajaran aktif Modeling The Way dengan siswa yang belajar menggunakan pembelajaran konvensional di SMK Taruna Pekanbaru.

Berdasarkan kemampuan awal siswa secara umum terdapat perbedaan antara kelompok eksperimen dan kelompok kontrol. Kemampuan awal juga berkontribusi terhadap kemampuan komunikasi matematis. Menghitung kontribusi KAM, akan di ketahui seberapa besar KAM memepengaruhi kemampuan komunikasi matematis. Setelah di hitung KAM sangat memberikan pengaruh yang kuat terhadap kemampuan komunikasi matematis.

Pembelajaran aktif Modeling The Way membuat siswa lebih bersemangat dalam belajar. Namun, ketika di lapangan peneliti sangat sulit mengontrol siswa, karena sebagian siswa ada yang tidak memperhatikan temannya menjalankan skenario kerja didepan kelas. Pada pertemuan pertama siswa cukup sulit untuk mengkomunikasikan hasil yang di peroleh di depan kelas. Disini peneliti harus memberikan contoh-contoh yang dekat dengan kehidupan siswa. Karena test yang akan di berikan peneliti lebih banyak mengenai soal cerita. Siswa harus mampu menulis, menggambarkan atau mengubah soal cerita tersebut menjadi simbol matematik. Tetapi di pertemuan selanjutnya siswa mulai berani untuk mengungkapkan apa yang telah ia peroleh. 
Berdasarkan hasil analisis penelitian dapat diambil kesimpulan bahwa hasil belajar matematika siswa dengan menggunakan pembelajaran aktifModeling The $W$ aydengan siswa yang belajar dengan pembelajaran konvensionalitu memiliki perbedaan baik. Ini terlihat pada perbandingan $t_{t}$ dan $t_{0}$ dengan $_{0}=2,06$ lebih besar dari $t_{\text {tabel }}$ padatarafsignifikan $5 \%(2,06<2,042)$. Tidak hanya itu, hasil belajar matematika siswa dengan menggunakan metode Modeling The Waydengan siswa yang belajar dengan pembelajaran konvensionalitu memiliki perbedaan baik pada kemampuan awal tinggi, sedang dan rendah. Dengan demikian ada perbedaan yang signifikanantara hasil belajar siswa yang menggunakanmetode pembelajaran aktifModeling The Waydengan siswa yang menggunakan pembelajaran konvensional.

Berdasarkan hasil tersebut telah menjawab hipotesis dari judul yang diangkat oleh peneliti yaitu Pengaruh Penerapan Metode Pembelajaran AktifModeling The Wayterhadap Kemampuan Komunikasi Matematis Ditinjau dari Kemampuan Awal Matematis Siswa SMK Taruna Pekanbaru.

\section{REFERENSI}

Abdurrahman, M. (2003). Pendidikan Bagi Anak Berkesulitan Belajar. Jakarta: Rineka Cipta

Asnawati, S. (2016). Peningkatan Kemampuan Komunikasi Matematis Siswa SMP dengan Pembelajaran Kooperatif Tipe Teams-Games-Tournaments. Jurnal Euclid , 3(2), 561-567.

Astuti Puji Siwi. 2015. "Pengaruh Kemampuan Awal dan Minat Belajar Terhadap Prestasi Belajar Fisika”. Jakarta : Jurnal Pendidikan Fisika. Vol. 5.

Bano, E. (2012). Peningkatan Kemampuan Pemahaman dan Penalaran Matematis Siswa SMA melalui Pendekatan Metakognitif Berbantuan Autograph. Symmet: Jurnal Pendidikan Matematika, 1(2), 149-159.

Cai, J., Jakacsin, M.S., \& Lane, S. (1996). Assessing students' mathematical communication. School Science and Mathematics, 96(5), 238-246.

Choridah Tresnawati Dedeh. 2013. "Peran Pembelajaran Berbasis Masalah untuk Meningkatkan Kemampuan Komunikasi dan Berpikir Kreatif serta Disposisi Matematis Siswa SMA". Jurnal Ilmiah Program Studi Matematika STKIP Siliwangi Bandung, Vol 2, No.2.

Febrinal, D. (2016). Peningkatan Kemampuan Komunikasi Matematis Melalui Contextual Teaching Learning di kelas VIII SMP 44 Sijunjung. Jurnal Kepemimpinan dan Pengurusan Sekolah, 1(2), $181-192$

Purwanto. (2014). Evaluasi Hasil Belajar.Yogyakarta: Pustaka Pelajar

Purwanto, N. 2002. Psikologi Pengajaran. Bandung: Remadja Karya.

Ratnadewi, C.B., Murtiyasa, B, \& Slamet HW. (2016). Implementasi Model Pembelajaran Modeling The Way Untuk Meningkatkan Keaktifan Belajar Siswa. Tersedia dalam: http://n http://eprints.ums.ac.id/19659/28/naskahku.pdf.

Shadiq, F. (2009). Kemabiran matematika. Diklat Instruktur Pengembangan matematika tidak diterbitkan. Departemen Pendidikan Nasional Yogyakarta.

Sugiyono. 2013. Metode Penelitian Kuantitatif Kualitatif dan R\&D. Bandung: Alfabeta.

Uno B. Hamzah. 2009. Mengelola Kecerdasan dalam Pembelajaran. Jakarta: Bumi Aksara.

Zaini, H. dkk. 2008. Strategi Pembelajaran Aktif. Yogyakarta: Pustaka Insan Madani.

Zainudin, T., Nissa, I.C., dan Agusfianuddin. (2017). Pengaruh Pendekatan SAVI (Somatis, Audiotori, Visual, Intelektual) terhadap Kemampuan Komunikasi Matematika Siswa Kelas VII MTs. Putra Narmada Tahun Pelajaran 2016/2017. Jurnal Media Pembelajaran Matematika, 5(1), 124-128 